\title{
Air conditioning spaceship earth: Peter Sloterdijk's ethico-aesthetic paradigm
}

\author{
Sjoerd van Tuinen \\ Zandpoortstraat 29, 9000 Gent, Belgium; e-mail: vantuinen@gmail.com \\ Received 6 August 2008; in revised form 28 August 2008
}

\begin{abstract}
This paper explores the convergence of anthropology and ecology in the recent work of Peter Sloterdijk. Firstly, it is argued that Sloterdijk proposes an important new interpretation of Heideggerian Gelassenheit for which I propose the English word 'relief'. The concept of relief rests on the substitution of ontological difference by what I propose to call 'natal' or 'natural' difference. Secondly, I will develop the significance of these concepts in relation to complexity theory and cybernetics, focusing on a key subject in the Sphären trilogy-insulation-and on a key subject in Sloterdijk's essays on Heidegger-homeotechnics. Thirdly, it will be shown how the concepts of relief and natal difference can be further developed into an ethico-aesthetic paradigm for experimentation with new technologies, based on a reinterpretation of the Gestell as total work of art. Finally, by relating Sloterdijk's work to that of Michel Serres, it will be demonstrated why, for Sloterdijk, this paradigm finds its exemplary modal in the spaceship.
\end{abstract}

The aim of this contribution is to explore the ecological potential of the recent work of German writer and philosopher Peter Sloterdijk, especially his trilogy entitled Sphären (1998a; 1999; 2004), and to develop it into an ethico-aesthetical paradigm for a politics of transhuman symbiosis. In an attempt to regain the connection between Heideggerian ontology and the 'ontic' sciences, I first demonstrate how, for Sloterdijk, the concepts of relief and natal difference must include the ontic in its widest sense, beyond the nature-culture divide. Though Sloterdijk himself is extremely wary of any "overshadowing ecological horizon" (2001a, page 299), I will then explore some ecological consequences that remain implicit in his work. This will be done by relating it to constructivist approaches of ecology and complexity, especially those of Michel Serres, Gilles Deleuze, and Félix Guattari.

\section{Relief}

Sloterdijk is a philosopher of what I propose to call relief, which can be defined as a postphenomenological interpretation of Martin Heidegger's contemplative principle of Gelassenheit: the serenity of the soul which allows us to linger with the 'things themselves', and which permits, in Heidegger's words, "another earth, another sun, upon which, sheltered from the menace of the world of technology, we may subsist and sustain ourselves." (1966, page 179). In most of his books, however, it is Sloterdijk's aim to "liberate Heidegger's thought in a language where it would be more right than in its own" (1988, page 10; 2001a, page 165). ${ }^{(1)}$ Thus, instead of Heidegger's proposal for a pious mindset of gratitude and passivity, the concept of relief comes to reflect modern processes of technological exoneration (Entlastung), moral relaxation (Entspannung), and economical 'de-scarsification' (Entknappung). In fact, Sloterdijk seems to argue, a "literal", "stubborn", (1988, page 9), "kinetic" (1989, page 260; 2001a, pages 29f) and "historical" or "evolutionary" (page 7) reading of Heidegger's de jure concept of clearance (Lichtung) demonstrates how we are already dealing with the product of a generous alleviation (Leichtung) (1989, page 260).

(1) All translations are mine, except where a published translation exists. 
In Sloterdijk's earlier work such a clearance through alleviation consists of the world-constituting refuge of "kynical" recalcitrance and poetic ecstacy (1988, pages $165 \mathrm{f}$ ); in his later works, it has become a hybrid of technology and anthropology conditioning the emancipation of the proto-hominid ecstasy of the Welt from the animal Umwelt through "air conditioning." (2001a, pages 159f, 204f; 2004, page 391). In both cases, the perversity of this reading of Heidegger lies in the fact that it paves the way for a "historical anthropology" of ontological difference, "without causing oneself to be misled by the contemptuous note of sworn-in Heideggerians, that something 'merely ontic' is being abused for determining something ontological. And what if precisely such a determination depended on a reversal through which contemplative philosophy could regain the lost connection with the investigative cultural sciences?" (2001a, pages 159f).

For Sloterdijk, an ontic revision of the concept of Lichtung is justified by the fact that today's being-in-the-world has long been "explicitated"(2) as a product of industrialisation, as a hybrid of nature and technology. As a consequence, Jakob von Uexküll's difference between Welt and Umwelt (von Uexküll, 1921)-which first explicitated the idea that the oikos, the mutual belonging of organisms and their environment, is something that can be destroyed (Sloterdijk, 2005a, page 945) — can no longer be interpreted - as did Heidegger (1995) - as a bivalent, ontological difference. The principle of relief must now be understood through a more complex and immanent principle of difference, which I propose to call natural or natal difference. ${ }^{(3)}$

\section{Natal difference}

Like so many philosophers writing after Heidegger, Sloterdijk approaches life as a medial and collective affair in which one assumes oneself (sich übernehmen) only by expressing, exposing, sharing, or inscribing oneself in something that has already begun (1988, pages 12, 22f; 2001a, pages 46f, 202f). If the world is never tabula rasa, then neither are we. Every subjective origin presupposes a presubjective dispersal without which there would be no existence. And for this ecstatic, even "perichoretic" (1998a, page 639) embeddedness to be properly affirmed, it depends on the contemplative principle of relief, a breaking out of the subjective reflex of self-identification regardless of the surroundings or an overcoming of aggressive "auto-mobilization" (1989, pages 42-48) whenever we are confronted with an outside world. One should no longer ask with Immanuel Kant the encompassing reflective question of 'what is man?' but one should ask, in a more Heideggerian way, 'where is man?' (Heidegger, 1998, pages 214f, 218f).

But who is this 'we' and how does it relate to what humanisms and social contracts traditionally exclude-nature? Other than the early Heidegger, for whom relief is attainable only through the rejection of the ontic world in its metaphysical totality from the perspective of individual Dasein's "own" being-unto-death, Sloterdijk attempts to think life from a flipside perspective which he calls its "coming-into-the-world" or, with Hannah Arendt, its "natality": the shared complexity and "unprejudicedness"

(2) In his Tate lecture from 10 December 2005, Sloterdijk himself translates the German 'Explikation' as 'explicitation': to unfold in the sense of explicitly making things and rendering things public (see http://www.tate.org.uk/onlineevents/webcasts/spheres_of_action/). For Sloterdijk, it combines Heidegger's poièsis ('bringing forth into the open') with what Bruno Latour calls 'articulation' and the 'explicitating violence' of modern avant-garde art (2004, pages 208f).

(3) For a discussion of this concept from a more existentialistic perspective see Sjoerd van Tuinen (2009). In 1999 and 2000 Sloterdijk gave a seminar on Spinoza and on Deleuze (for traces, see, in particular, Sloterdijk, 2001b). I intend natal difference as a more existential yet ontologically synonymous concept of the natural, Spinozist difference between natura natarans and natura naturata. 
of the "still" of "being-born" (1989, pages 151f). For both of them, not 'throwness' but "bornness" is the key to a nonteleological theory of man's finity. Being born means that one is traversing an Offenheit, entertaining an ecstatic relation with other people and being under constant pressure of one's engagements in technological, artistic, social, and political-in short, ontic-affairs. Gelassenheit is still an important value in this situation of indissoluble immersion, but it should no longer be aspired to from the perspective of its being-not-yet. Rather, it must be looked for in the "unprejudicedness" of the "as yet" of "being-born" - that is, from the perspective of its total situatedness (Arendt, 1958, pages 10f, 157f, 170, 221f). A relief cannot begin with a turn against the actual world, but is always the result of an affirmation of our shared public engagement without which we would be powerless (Sloterdijk, 1988, pages 115f; 1989, pages 151f; 1994, page 280; 2001a, pages 42f; 2004, pages 389f).

But Sloterdijk goes further than Arendt and argues that Mit-Sein can never be the privilege of humans. What is necessary today is first and foremost "a new politics of trans-human symbiosis", a politics of living together that is not the privileged right of humanity alone (2005a, page 944). Consider one of his favourite examples, one that teaches us how to move from our understanding of nature as mere Umwelt, a natura communis that functions as indifferent collector of humanity, to nature as the monstrous potential of the Welt and the differentiating power of natura naturans: if Dolly is no longer a sheep born from sheep, then neither would the homo clonatus be a human born from humans. Yet, at the same time, this human is precisely a humanmade human, or homunculus (Sloterdijk and Heinrichs, 2001, page 108; Sloterdijk, 2001a, pages 166, 215). At work here is a technology-mediated, intergenerational, or natal difference, which, by differentiating nature into a process with two sides - one of production, or natura naturans, and one of its products, or natura naturata - frees the creative force of life from its fixation on the side of the produced and marks what has already been generated with a processual excess over itself. Firstly, this difference forces us to understand technology as a production process that does not differentiate between nature and 'human' technology in an absolute way. Secondly, it disallows us to reduce the essence of life to the prescriptive laws of what actually exists or to disconnect it from the laws of self-transgressing becoming. Thirdly, it makes us realize that life, no matter whether it is defined biologically, ecologically, or morally, cannot be restricted to the privileged domain of an essentialistically defined humanity. Hence, it is what Sloterdijk calls "a new 'principle' of difference" - that is, an "ontological difference without metaphysics" (1988, page 96).

Sloterdijk's critique is reminiscent of Jacques Derrida's deconstructions of the teleology of anthropocentric discourse under the highly ambiguous banner of "the ends of man (fin des hommes)" (1982, pages 109f). In his deconstructive readings of Heidegger, Derrida had already taught that a morality-free, or "unprejudiced" approach to humanity can be based only on a difference that cannot be appropriated. For Sloterdijk, this means that due to their natal excess humans are never completely at home, yet neither could or should they be. What is needed is "a biopositive, non-illusionary but indecipherable, because foetal, reservation of the world (Weltvorbehalt)" (1988, page 94). Contrary to Heidegger, Sloterdijk continues to call his work an 'anthropology', even though it turns out to be an "anthropo-monstrology" (2004, page 864). In Heideggerian terms: we can never come to ourselves (bei sich), but constantly have to deconstruct and reconstruct our shared "house of Being." Being-born does not simply equal moving into the house of Being; rather, it is a "move to what lies beyond"-namely, an entire "human park", an irreducible situatedness in which 
humans constantly have to assume themselves. ${ }^{(4)}$ In this process of construction the difference between nature and technology cannot be one of kind, but only of degree. Firstly, because, even though man's relation to technology may be uncanny (unheimlich) and informed by monstrosity (das Ungeheuer), the monstrous is precisely the positive opportunity for new forms of life - that is, of natal difference. For what is "nature in its exact sense", if not "the power of birth" (1988, pages 64f; 2001a, pages 154, 290f)? ${ }^{(5)}$ And, secondly, other than is the case in ontological difference, thinking natal difference is not a solitary meditation of what happens on 'the other side', which can be approached only through negation by a human Dasein that is locked up in its own finite and estranged technology. Rather, and here lies the significance of constructivism for ecology, "the innate negativity of the human position towards nature can turn into a positivity, if humans themselves, spoken figuratively, arrive at the 'other side' sufficiently enough-more precisely, on the side of naturating" (2001a, page 294). Once technological development has progressed enough in order to be indiscernible from natural production processes, nature or physis itself appears as the integral production process in which we are embedded and with which we cooperate. A relief from onesided production processes and technological exploitation must then include not only 'us', but also the generative pole of 'nature' itself and would thus allow for a more resilient approach to ecological problems.

\section{Poièsis in complexity 1: insulation}

Ever since his Critique of Cynical Reason it has been an essential part of Sloterdijk's project to reconcile naturalism with the "ancient European virtues of forbearance" (1987a, page 540) that recur in contemplative phenomenology. In order to achieve this, Sloterdijk, in his recent works, joins with advocates of complexity theory and cybernetics such as Gotthard Günther, Niklas Luhmann, Vilém Flusser, and Michel Serres. It is true that, as Heidegger never ceased to remind us, in new technologies and digital interfaces, modern transcendental subjectivity-reformatted into that of the "observed observer" - recurs stronger than ever. But it is precisely the continuation of phenomenology itself which demands a cybernetics or systems theory that grasps subjectivity "beyond ego and will" (1990, pages 82, 89) in a "historical compromise between cybernetics and personalism" (2001a, page 223). Contrary to Heidegger's analysis of the essential poverty of modern subjectivity as the feedback system of technology, Sloterdijk understands cybernetics as the discovery of life beyond property and lack, because it was the first to theorize scientifically what could previously be understood only as intolerable and irrational 'scum' between Being and nothingness: the functioning of information as a third term between subject and object, or between nature and culture, turning reflexivity itself into a mechanism (2004, pages $740 \mathrm{f}) .{ }^{6}$

(4) For Heidegger's use of the concept of sich übernehmen, which comes very close to that of Sloterdijk, see his Beiträge zur Philosophie (1989, page 297): "Gleichwohl stehen Dasein und Mensch in einem wesentlichen Bezug, sofern das Da-sein den Grund der Möglichkeit des künftigen Menschseins bedeutet und der Mensch künftig ist, indem er das Da zu sein übernimmt."

(5) Instead of Seinsvergessenheit, Sloterdijk therefore prefers the notion of "Muttervergessenheit" (Sloterdijk and Heinrichs, 2001, page 167) Like Deleuze and Guattari (1987, pages 404f), Sloterdijk refers to metallurgy, the ovens of which were long seen to function as articial wombs, as the prototype of these sciences that have "condemned us to alchemy", an "onto-anthropo-alchemy". But, whereas the old concept of alchemy was one of the (re)production of nature, the new one mainly concerns an acceleration of nature and thus, for the first time, the old saying natura artis magistra truly applies (2001a, pages 297f).

(6) An important reference of Sloterdijk for this post-Hegelian concept of information is Günther's Das Bewusstsein der Maschinen (1963), which makes a crucial difference between "classic" and "transclassic" technology. 
Cybernetics, he argues, is the transformation of phenomenology into a veritable constructivism, which treats beings not as Bestand, enframed and domesticated in an ill-founded world picture, but as events in a complex and dissipative process, in which the self undergoes a transition "from a priori-regulation to a posteriori-regulation" (2004, page 870). In other words, whether one adopts an ecological, genetic, political, social, or even poetic stance, what is at stake is "a cybernetic concept of justice" (1990, page 81) in which 'we', as information-processing animals and thus as medial protagonists of natura naturans, are engaged in a process not only of self-formation (humanism), but also of world formation (ecology).

For example, consider what has been according to Sloterdijk the most important 'event' in the history of the Lichtung "from below" (2001a, page 168) that of anthropogenesis: "the ontological event", the "world-effect" (2004, pages 359, 214), or "perhaps the event par excellence" (2001a, pages 159, 206). To account for this evolutionary falling out of the Umwelt, Sloterdijk offers a strongly Deleuze-inspired theory of islands or cybernetical spheres, which describes human facts as constituted through two codependent factors of isolation and self-extraversion or self-expression.

Deleuze, in his early essay on "Desert islands" ([1953] 2004]), described how islands are not just constituted by maritime erosion and terrestrial emergence, but also constitute an "origin, radical and absolute" in themselves, as soon as the original vectors of creative movement, their "first beginning", are taken up and prolonged by humans in a "second beginning". In the extreme case of a perfect continuum between geography and human imagination, in which an exemplary resident of a new island carries further the island-creating élan, humans would automatically function as the pure consciousness or Geist of the island and the island would function as the dream of humans. One would then have "an Idea of humanity, a prototype, a man who would be almost a God ... a human being who precedes itself. Such a creature ... would be the island itself, insofar as it imagines and reflects itself in its first movement ... ready to begin the world anew" (Deleuze, 2004, pages 10f).

However, since the continuum of the deserted island and its inhabitants is de facto always ruptured-and for this reason Sloterdijk will argue that the concept of biological humanity is in essence of a religious nature only (2004, page 394; 2005b, pages 228f) - the ecological question rises as to how the two beginnings, that of humankind and that of geographical islands in the widest sense, can actually bear each other. Sloterdijk agrees with Deleuze that human beings are not identical to the movement that puts them on the island but are always the product of a second birth and, in accordance with the principle of natal difference, of a whole series of 'rebirths'. But, in addition, he argues that these rebirths are nonetheless dependent on a first insular emergence as a necessary minimum. His 'spherology' offers a sophisticated theory of the minimal conditions for the initially impersonal process of creative selforganization which isolated and distanced the proto-hominids from their environment in what he calls "anthropogene islands" or "anthropospheres". What is necessary is an insular climate that spares its inhabitants from the hardships of the African savannah. This can be a geographical island, such as an oasis in the desert or the earth's greenhouse effect, but that is not enough. There must have been a highly specific atmosphere that "spoils" its inhabitants in such a way that it allows for an excessive "world" to appear (2004, page 389). In short, according to Sloterdijk, such an anthropospheric climate is the result of a process of two original, proto-hominid and proto-cultural "mechanisms" of 'de-deserting' and 'de-distancing' (Entfernung): island formation through group inclusion in intimate "spheres" and an increase in the range of action through the medium of distance-bridging, primitive technology 
(1993, page 19; 2001a, page 153; 2004, page 389). ${ }^{(7)}$ Together, these mechanisms account for an ecstatic deterritorialization from an extensive environment (Umwelt) and a reterritorialization towards an intensive "inside space" of ecstatic comfort through proximity (Welt) or, more prosaically, from the 'found' to the 'made' - that is, from nature to culture, in a "secondary greenhouse effect" (1999, page 42; 2001a, pages 171f; 2004, page 315).

"It is as though the island had pushed its desert outside", Deleuze writes (2004, page 11). But what is pushed outside? According to Deleuze, "what is deserted is the ocean around [the island]" - that is, the circumstances due to which the island has become a desert island. However, this desertion is not necessarily effectuated in the usual sense of a repression of the natural environment. As Sloterdijk argues, the expression 'savannah' must be understood as being of another order than the hominid world and demands a "reorientation from the relevance of the environment (such as natural enemies and food sources) to the relevance of a properly human world" (1989, page 259; 2004, page 493). The sense of talking about the "emergence" of spheres in complex circumstances is precisely that the desertedness relates not to the natural habitat of proto-hominids, as modernist discourse and its objectified concept of nature would suggest, but to the original animal way of being-in in a natural milieu. In other words, the presubjective and preobjective anthroposphere is not a Welt that emerges simply by repressing its Umwelt. The concept of spheres indicates precisely that humans "are never in fact naked in totality, in a physical or biological environment of some kind, but that we are ourselves space-creating beings, and that we cannot exist otherwise than in these self-animated spaces". (8)

Even though there may be tensions between the natural processes that make an island emerge and the processes that start off with proto-hominid or human-made technology, nature must be understood as the nonoutside of these processes. Anthropospheres are "collectors of Being", islands of "vigilance" that constitute the "immemorial liaison between alertness (Wachheit) and truth (Wahrheit)" through which "Nature itself opens its eyes within humanity" (2004, pages 359, 494, 671f). Our lifeworlds, then, are "human parks", cybernetical spheres of coinhabitation that do not exclude nature, but which are themselves hybrids of nature and culture, or of physis, technè, and poièsis. Even in the extreme case that the Umwelt, including such variables as the weather and the soil, has been immanentized and explicitated completely in "absolute islands", such as shopping centres, greenhouses, or space stations, nature all but disappears (2001a, page 197; 2004, pages 490f; 2005b, page 267). That is why, for Sloterdijk, Heidegger's diagnosis that technological enlightenment occurs at the cost of ontological enlightenment is ultimately still founded on an uncritical concept of nature. A relief of nature and ourselves from short-sighted technological practices cannot depend on a turn away from technology to a realm of things themselves inaccessible for technology, but depend only on "a Turn in the process of technology itself", adequate to the concrete and complex situation we find ourselves in. If nature is an "autoplastic", "self-constructing hypermachine" (Sloterdijk and Heinrichs, 2001, pages 115, 222; Sloterdijk, 2004, page 494), then we are not so much ontologists as "second order engineers" (page 296). Indeed, as Sloterdijk argues, today "spacetravel serves contemporary philosophy as the radicalization of the epoché" (1989, page 306; 2004, page 362).

(7) I will not discuss these topics further. In his essay "Die Domestikation des Seins: die Verdeutlichung der Lichtung", published in Nicht gerettet (2001a) Sloterdijk, highly influenced by the work of German anthropologist Dieter Claessens (1993), subdivides both concepts into four mechanisms - of 'isolation', 'deactivation of the body', 'neoteny', and 'transference' (2001c, pages 175f) and in nine 'dimensions' that form the minimal conditions for a complete explicitation of the anthroposphere-chirotope, phonotope or logotope, uterotope or hysterotope, thermotope, erototope, ergotope or phallotope, alethotope or mnemotope, thanatotope or theotope, and the nomotope (2004, pages $362 f$ ).

(8) http://www.petersloterdijk.net 


\section{Poièsis in complexity 2: homeotechnique}

For this reconciliation of Gelassenheit and technology, Sloterdijk, following the founder of homeopathy, Samuel Hahnemann, and extending his own concept of "self experiment" (1996, pages 13f; Sloterdijk and Heinrichs, 2001, pages 7f), proposes the concept of 'homeotechnique' (page 227), the technology used for operating on materials that are of the same ontological quality as the operator. It is contrasted with "allotechnique", the "contranatural" or "estranged" technology that treats materials as being of another ontological quality. The allotechnique, corresponding to Heidegger's conception of technology, determines Western metaphysics from Athens to Hiroshima (Sloterdijk, 2001a, pages 214, 275f). However, technologies and modes of production such as genetics, artificial intelligence, neurosciences, and robotics depend ever less on one-way operations instrumental to an enframing, demiurgic will to power. Rather, Sloterdijk argues, they increasingly depend on a "new alliance with the worker of nature (Naturarbeiter)" (2005b, page 45) and "regenerative energies" (pages 363f). And this cannot but lead to the growing importance of the principle of adequacy according to which such a mode of production should 'want' nothing except what the "things themselves" are from themselves or can become from themselves - "all "material' would then be understood and operated upon departing from its proper obstinacy (Eigensinnigkeit)" (1987b, page 81; 1989, pages 148f; 2001a, pages 53, 227; Sloterdijk and Heinrichs, 2001, pages 29, 82, 330f).

This Eigensinn or Eigennatur (2001a, page 226) is illustrated with an example from Spinoza: "If, for example, I say that I have the right to do whatever I like with this table, I am hardly likely to mean that I have the right to make this table eat grass" (Tractatus Politicus, IV, 4; cited in 2001a, page 227). We really are the quasi-demiurgic species that artificially manipulates nature. But this is possible only through the practice of homeotechnique which makes nature and humans take part in the same continuum of what Heidegger calls "bringing-forth-into-the-open". Combined, the 'gynaecologization' of Heidegger's critique of technology towards an understanding of natal difference instead of ontological difference and the cybernetical interpretation of Deleuze's theory of deserted islands offer a principle of natural or natal difference that puts Gelassenheit back into nature, making the "real history of the Lichtung" described above coincide with the "natural history of Gelassenheit" (Sloterdijk, 2001a, page 159; cf 1993, page 19). Or in terms of modern philosophers of nature such as Alfred North Whitehead or Deleuze: the "things themselves" do not need to be contemplated in a phenomenologically attuned consciousness, since they are themselves the contemplations of their own production process (Deleuze and Guattari, 1994, pages 6, 212).

Another consequence of new technological developments is that they demonstrate how the politically legitimating doctrine of humans as mangled creatures (Mängelwesen) fails. Arnold Gehlen regarded our "lack of means" (Mittellosigkeit) as an essential trait. Sloterdijk reverses Gehlen's thesis by focusing on relations that are enabled by technology and other mediations, such as money (2004, pages 703f). As Arendt had already shown, instead of our being burdened with neoteny (to be born prematurely), our natality is directly related to our ontic capacity to inaugurate new beginnings. It is the possibility to escape from "pernicious routines" (2005b, page 415) in favour of the new. We have never been completely bound to the burdens and laws of the "human condition", but have always already also engaged, to a varying degree, in an experimental project of "air conditioning". This takes on a very literal meaning, since, as Sloterdijk argues by exploiting a "cybernetical" conception of Karl Marx's and Friedrich Engels's pre-ecological "all that is solid melts into air", the anthropological climate is not simply the natural infrastructure of which humans are superstructure effects. 
Rather, there is a circular causality in which "at each time the epiphenomenon of one dimension is the basis of the other and vice versa" (2004, page 496). In fact, echoing Latour, "we have never been revolutionary", (page 86) because we are-according to Herder - "creatures of air (Zöglingen der Luft)" and "in truth the consequences are more fundamental than the foundations" (2004, page 496; 2005b, pages 357f). The concept of humanity no longer refers to an object of worship or of reflexive knowledge, but to a "generality" that contains "incalculable complexities" (2001a, page 157). At best, it refers to a medium or stage, "an eye through which Dionysus observes himself", (1990, page 82) or upon which "Being" or "natura naturans becomes a cultural drama" (9) (1989, pages 154f; 2004, pages 177f, 194).

But if man is no more than, translated back into Heideggerian discourse, a "regional possibility of Lichtung and a local energy of gathering (Sammlung)" (2001a, pages 222f, 338f) and not the eternally fixed scene of what takes place, then what remains of the 'earth' and of our ecological responsibilities? Is it enough to only "save our selves", as Al Gore wants? ${ }^{(10)}$ Or is it finally possible to unite humanism and ecology, ontology and science, or political subjectivism and ecological objectivism in a political ecology, as Latour in a recent article on Sloterdijk seems to suggest (Latour, 2007)? If today there is an ecological crisis of earth, then how precisely is this "simultaneously the first crisis of humanity" (1994, page 378)?

\section{Earth: an ethico-aesthetic paradigm}

"Full of merit, yet poetically man dwells on this earth" (Heidegger, 2000, page 50): with this quote from Hölderlin, Heidegger put into perspective the great modernist project of missionary, colonial, and scientific explorations of the earth. To put it bluntly: an earth without heaven remains "from the perspective of the history of being the erring star (Irrstern)" (cited in Sloterdijk, 2001a, page 81; 2005b, page 34). His diagnosis is in line with other dominant interpretations of modernity, such as Sigmund Freud's, for whom the Copernican revolution and all that follows from it is most of all a humble lesson in the decentered position of humanity in the cosmos. It is this humbleness that is contested by Sloterdijk, because it is derived from an ultimately hypocritical and anticonstructivist metaphysics. "The most important fact of Modernity is not that earth orbits the sun, but that money orbits earth" (2005b, page 79). Rather than by contemplating the limitations of being stuck on earth, he commits himself to a more radical modernism which includes both merit and poièsis: the constructivist 'explicitation' or immanentization of the earth globe.

It is, of course, true that post-Copernican globalization coincides with the history of imperialist capitalism and the exploitation ${ }^{(11)}$ of the earth as cartographic object of active cultivations and speculations: it is the long, linear story of entrepreneurial "deterritorializations" of productive energies from the abstract and ideal towards "reterritorializations" on the concrete and interesting. But contrary to many inveterate ecologists, for whom the earth still possess the transcendent qualities of the civitas dei, Sloterdijk does not accept capitalism solely as a threat. Rather, it is for the earth globe as joint venture of nature and culture, or of greenhouse and Warenhaus, that in Nicht gerettet: Versuche nach Heidegger (2001a) and Im Weltinnenraum des Kapitals (2005b) - in the philosophical tradition of Friedrich Nietzsche's Zarathustra which sought "to stay true to the Earth" — he proposes a "geodicy" (2001a, pages 369f).

${ }^{(9)}$ Despite the fact that humanity refers to nothing except "the disadvantageous location 'I'" (2005b, page 230).

(10) A reference to Al Gore's 2007 slogan for his series of 'Live-Earth' concerts.

(11) As Serres has pointed out, to explicare is the common root of both to explain and to exploit (2000a, page 116). 
Sloterdijk's "juridical" defense of the earth starts with an affirmation of a new space in human consciousness, opened by the death of God and the rapid technological explicitation of nature: human-made or de facto "monstrosity", or, in more aesthetical terms, a human-made, but nonetheless immeasurable, 'sublime' (Oosterling, 2007). For Kant, the experience of the sublime makes explicit the inadequacy of the categories of the understanding. For Jean-François Lyotard, it shocks the bourgeoisie out of its judgments of taste. But, for a constructivist, the sublime consists of an unavoidable, "immediate relation to the over-complex" (Sloterdijk and Heinrichs, 2001, page 28).

The monstrosity of the earth consists in the explosion of the old European space of possibility called earth (2001a, page 369). The age of terrestrial globalization, led by the modernist imperative of "where there was nature, there infrastructure shall come to be" (2004, page 554), ${ }^{(12)}$ was left behind in 1944 when the first worldwide currency was established with the gold parity between the US dollar and the British pound sterling and when we could see the globe in its entirety from outer space in 1969. As Sloterdijk argues, what we call 'globalization' today should rather be called the process of transforming earth into a continually modified total work of art (Gesamtkunstwerk) (2004, page 811; 2005b, page 415). Earth is a globe which, after its complete explicitation, consists only of a "general externality" of flows of capitals and signals (page 160). The notion of "externality" refers to the relatively new impossibility of an asymmetric action without consequences, finally rendering concrete the abstract fact that the earth is round. It compels us to a reflective consciousness of the earth as a shared Offenheit, the artificial stability of which is fragile and complex. And it demands a new ethics of technè and poièsis. For, as the cynical resignation of contemporary globalized ecological consciousness demonstrates, the typically modern, self-reflective and self-guiding optimism concerning the subjective operability and appropriability of what is explicitated is no longer obvious. What appears is "the infinite as enclave in finite circumstances" instead of vice versa, an "upward abyss" (2004, page 495) which takes the form of an indissoluble "advance of the object" over the subject (2004, pages 79f).

This advance, Sloterdijk explains, was prefigured by modern art, because it was the first to explicitate "the absoluteness of production" and the obstinacy of the art reception. Similar to Lyotard's discussion of the avant-garde, Sloterdijk discusses surrealism, in analogy to terrorism, as the "procedure of using violence neither against persons nor against things, but against unexplicitated cultural relations" (2004, pages 157f). ${ }^{(13)}$ For a constructivist, surrealism is interesting, firstly, because through its constructions it makes us question the detrimental routines and transcendental dogmas that guide us as means of valorization, but secondly and more importantly, also because, by creating dissensus between the side of production and the side of reception of products, it necessitates critical reflection to extend from the receptive to the creative side. Today, not only has the public itself become a total work of art, but also the artist has to be his or her own critic as well. Nature is no longer the indifferent theater for human dramaturgy, but becomes part of the play itself (1989, pages $309-310)$. Critique and creativity now cooperate no longer as art practices in the public sphere, but of the public sphere (Oosterling, 2007): "In this situation the

(12) In Holland the latest nature-saving invention is the 'ecoduct': a viaduct or flyover for animals crossing the highway.

(13) The turbidness in these cultural relations is described by Sloterdijk in analogy to Michel Foucault's archaeology of 19th-century man as "empirico-transcendental double": today earth is both the object of human interventions and their limiting ground, resulting in a continual tension between the juridical and the factic level (2005b, page 45 ). 
constraining parameters appear as co-original with the 'originary' impulse, or more precise: they precede it, similar as to when the commentary gets ahead of the text and the staging tears the piece to pieces - and rightly so, since each author should pay for having been so wanton to write his work unilaterally and without permission" (Sloterdijk, 2005b, page 298).

If we apply this principle of immediate feedback typical of modern art to that of natal difference in technological and ecological production processes, then earth comes to be understood as a "formless monstrosity": a source of conditions and possibilities for construction that remains immanent to the production process and its products. The globe is no longer only the transcending limit of all currently established forms of subjective knowing, acting, and judging, it is also the objective potential for their creative transformation. That is, insofar as it comes to be effectively experienced as a singularity which cannot be understood, but can only be creatively continued through the "unicity of the encompassing and uncanny" home of life (2001a, pages 369f; 2005b, pages 15f). In Sloterdijk's words, the creative are those, "who prevent the whole from sinking away in pernicious routines" and who form "the elan of a civilization, which keeps its potential by extending, improving and differentiating" (2005b, pages 414f). Yet, today, "what is missing is an art of thinking which serves the orientation in a world of complexity" (Sloterdijk and Heinrichs, 2001, page 353).

By borrowing a concept from the English translators of Guattari, I propose to call this Denkkunst an ethico-aesthetic paradigm. It reinterprets Friedrich Hölderlin's poetic dwelling in terms of what Sloterdijk calls a "global work of installation art" - installation' deriving etymologically from the German stellen that dominates Heidegger's concept of the Ge-stell. The monstrosity of the earth is that the lifeworld has gained a museum-like quality. It demands an aesthetic attitude by which "one transfers the form of the museum to the system as a whole and moves around in it as a visitor" (2004, page 818). But, different from the old-fashioned museums of modernity, there remains a responsibility of the creator with regard to the thing created. And even if all that is new emerges from the midst of what already exists, there are no preestablished schemas to guide this process (2004, page 87). Ecology presupposes earth as much as it is conditioned by it. There remains an alterity in the object, or in the "things themselves", that must be respected in a reflective delay before further subjective experimentation can be undertaken. If we want to remain faithful to Spinoza's project of explicitating nature to its full potential, this implies a critical concept of caution, or an "immunological" (14) outlook on culture and nature, based in "post-metaphysical learning processes" (1990, page 184; 2001a, page 301). In this perspective, modes of existence are directly related to modes of achievement. ${ }^{(15)}$ Such would be the reformatting of a humanistic and imperialistic world horizon to an ecological and truly global, or with Sloterdijk: a finally "monogeistic" one.

\section{The natural contract: constructivist ecopolitics}

Sloterdijk's favourite "model of the world" (2004, page 311), especially for discussing the ecopolitical importance of a creative "consciousness of atmospheres", is the boat,

(14) Sloterdijk explains that the merit of an immunological approach is precisely its metadiscourse for comparing different constructions - whether metaphysical or technological - in their functioning as "life support system" (2000; 2004, page 322).

(15) Or: "Whilst the classical concept of nature reduces the being good of the real to the timeless images of perfection, the works of art of the modern world have to prove their being good in the probation of multiple generations of praxis. Here nothing is good, what cannot always be improved. Being means being tested. What is predominantly evil or bad is self-eliminating; what is predominantly good has self-propagating and self-continuing virtues" (2001a, page 232). 
or, in its more advanced form, the spaceship (page 505). As "absolute island" in outer space, it better approximates his concept of the earth than Heidegger's Lichtung in the forest (an "anthropogene island") or Deleuze's desert island in the ocean (a geographical island), because it has interiorized, though not sublated, the totality of nature in all its monstrosity. In Im selben Boot: Versuch über die Hyperpolitik (1993), the allegorical model of "being-in-the-same-boat" is used for a cybernetical theory (the Greek kybernetes meaning steerman) of the human experimentum mundi (Ernst Bloch, cited in Sloterdijk, 1996, page 65; 2001a, page 290). For Sloterdijk, it is directly related to Bismarck's self-legitimating definition of politics as 'art of the possible'. Though the reader might be surprised by such a conservative formula - especially because the boat is such a thoroughly capitalistic model for investment first found, after Sophocles's canonical metaphor of the "ship of state", with 15th-century Portuguese seafarersit is Sloterdijk's argument that we still do not know what this metaphor means today, since, for him, it models politics on "the art of what is atmospherically possible" (1999, page 1013, my emphasis).

Of old, the ship stands for a radical in situ principle, derived from the public in-between of the being-together of political animals in shared communities and environments. Once it sets sail, its significance lies first of all in the fact that it cannot be capitalized upon from the outside and that anyone on board must start from and remain immanent to really existing, natural, social, and solidary ties. The ship is a "social contract" that unites its crew in equality in the face of the monstrous ocean, as in the case of the arc of Noah, which, for Sloterdijk, serves as the "not sufficiently understood symbol for the ontological coevalness of post-Flood creatures" (no date). Our contemporary aircrafts and space stations, as models for the whole planet, differ from this model only insofar as these homeotechnical creations bind together not only creatures, or natura naturata, but all of nature, including what I have previously referred to as 'natura naturans'.(16) As a consequence, if the maritime contracts of old were still, in an extended sense, de jure and tied to appropriating investments and exploitative ventures, Sloterdijk argues that this can no longer be said of our de facto complex relation to "earth", which must now be understood as being already for itself "the powerful reason-ground for being together (Der starke Grund, zusammen zu sein)" (1998b).

Today, "Spaceship Earth" (a notion adopted from the American architect Buckminster Fuller) unites host and parasite in a symbiotic relationship, because it is the shared ground of natal difference and the extralegislative condition of the new. To the earth belong all the gestures of birth: it delivers, it bears, it generates, it upheaves, it releases (1989, page 326). Yet, it is not an indifferent or rational foundation. Rather, it is a fragile reservoir of possibility; it is "a local area for symbioses of common improbability" (1989, page 326), a field for collective experimentation in which bornness and boldness (Getragenheit und Gewagtheit) are the same (1989, page 326). It is, as Serres argues, held together by an unwritten "natural contract" (2000b). Plex-words or weaving-words such as "complexity' refer to the "cord" which ties the domain of law and politics to that of physis and the local to the global. They are tropes for the purely relational being of the world and offer a vocabulary for a factual cordiality and an "objective morality" between nature and man in which, contrary to the "social contract", the subject is the collective assembly, including nature, itself. Only secondarily does the cord become the kind of contract in Jean-Jacques Rousseau's sense - that is, a stringent or juridical knot which excludes the nonlegislative

(16) For the same argument, see Whitehead (2006, page 148), "All we know of nature is in the same boat, to sink or swim together", or even James Lovelock's Gaia hypothesis. 
space of nature. We are citizens of the earth (Erdbürger) before we are citizens of state (1989, pages 307, 318). In an early argument for the priority of the aesthetic over the juridical approach, Sloterdijk therefore concludes that "as long as people don't become aware of their poetical world contract, as long as they don't achieve the poetical sharing of the indivisible, it will be in vain to want to bind them to legal forms of social contracts" (1988, page 139). ${ }^{(17)}$

The spaceship explicitates the earth and all the natural, bodily, and atmospherical mediations of our affairs as the forgotten terms in juridical oppositions such as friendenemy, culture-nature, mind-body, subject-object, and, ultimately, politics-ecology. By implicating (Sloterdijk and Heinrichs, 2001, page 353) them as tertium datur (Sloterdijk, 2001a, page 172) or "included middle", Sloterdijk's "biosophy" (2004, page 24) supplements ethics with a prosthetics. Man's media are, in fact, constitutive of an openness and creative force that channels inventions. ${ }^{(18)}$ A space station is nothing but a "lifeworld prosthesis", an "environmental control and life support system", or "an implant of a lifeworld in a non-lifeworld", which, through its Eigendynamik, gives intelligent feedback that we can no longer ignore (2004, pages 322, 493; Sloterdijk and Heinrichs, 2001, page 217).

Finally, the ship offers a model for an ecological, and no longer ontological, relief from the customary ways of relating to the future as a catalogue of miseries and disasters, because it is always "engaged [verlobt] with the prevailing winds" and lets itself be borne "unconditionally" "into the Open" (19) (1993, pages 7f; 1994, page 60; $2005 \mathrm{~b}$, pages 397f). Heidegger describes Gelassenheit as the result of a turn to ontological difference (Kehre), a movement through which, in a "flash", the Lichtung reflects its own light and by which its occupant would be restored to its 'proper' essence (Heidegger, 1962, page 43). For Sloterdijk, this flash is the enlightenment of arriving-into-the-differential-openness-of-the-world, a natal movement which, after biological birth, is repeated each time a solution to a particular problem presents itself. In terms of the Kehre and possible changes of current, we must not seek a total re-turn, re-volution, or re-version (Umwendung) but, more adequate to the complexity of our world, ongoing 'inversions' and new 'explicitations' in the plural (Verwindungen). (2001a, pages 72f, 328f). Ultimately, Sloterdijk's main problem with both phenomenology and revolutionary humanism or ecologism lies in what he repeatedly refers to with Niklas Luhmann's concept of 'reduction of complexity' (Sloterdijk and Heinrichs, 2001a, page $80 ; 2001$, page 47). Instead, he offers a polyvalent 'grammar of shared situations' and of 'being-in-the-middle-of-it' that could function as a means of orientation and invention in contact and intercourse (Verkehr) with a concrete and complex world (1999, page 835; 2005, pages 27, 277f; Sloterdijk and Heinrichs, 2001, pages 351f). "The seafarer of the future navigates in coherences, in which there can no longer be revolutions in the old style, but extroversions from moribund and biased structures, new contrarities to be baptized and fatal routines-turning movements, through which the meaning of active, conscious, shared life in the multiple mobilized world necessarily changes" (page 80). Such inversions are not 'countermovements' (page 75) but movements of 'cooperation' and 'invention' in which problems appear only when

(17) One can easily recognize in this early programmatic statement Latour's strongly Heideggerinspired Dingpolitik (for example, see 2005, pages 14f). In this context, it is interesting that already in 1987 Sloterdijk describes his work as the attempt of "thinking Weltoffenheit outside of the selfreferential monotony of twaddle and granting the word to things, better: making the word into the sounding board of reality" (1987b, page 82).

${ }^{(18)}$ Or, as Latour wonders: "can one simultaneously cultivate the passions and those of attachment?" (2007).

${ }^{(19)}$ For Deleuze on nomadic thought and 'being-in-the-same-boat' see Deleuze (2004, page 255). 
circumstances offer their solution: turns of technology against technology, of capital against capital, of war against war, of science against science, and of media against media (pages 76f). In order for philosophy to reach such an affirmative attitude towards the future, it must become the aesthetics of the superfluous and of a monstrous dissensus that further inspires a culture of critical creativity. Such would be the relief of natal, or natural, difference.

\section{References}

Arendt H, 1958 The Human Condition (Doubleday/Anchor Books, New York)

Claessens D, 1993 Das Konkrete und das Abstrakte: Soziologische Skizzen zur Anthropologie (Suhrkamp, Frankfurt am Main)

Deleuze G, 2004 Desert Islands and Other Texts translated by M Toarmina (Semiotext(e), Los Angeles, CA)

Deleuze G, Guattari F, 1987 A Thousand Plateaus translated by B Massumi (University of Minnesota Press, Minneapolis, MN)

Deleuze G, Guattari F, 1994 What is Philosophy? translated by H Tomlinson, G Burchill (Verso, London)

Derrida J, 1982 Margins of Philosophy translated by A Bass (University of Chicago Press, Chicago, IL)

Günther G, 1963 Das Bewusstsein der Maschinen (Agis, Baden-Baden)

Heidegger M, 1962 Die Technik und die Kehre (Klett-Cotta, Stuttgart)

Heidegger M, 1966 Questions III translated by A Préau (Gallimard, Paris)

Heidegger M, 1989 Beiträge zur Philosophie (Vittario Klostermann, Frankfurt am Main)

Heidegger M, 1995 The Fundamental Concepts of Metaphysics: World, Finitude, Solitude translated by W McNeill, N Walker (Indiana University Press, Bloomington, IN)

Heidegger M, 1998 Kant und das Problem der Metaphysik (Vittorio Klostermann, Frankfurt am Main)

Heidegger M, 2000 Über den Humanismus (Vittorio Klostermann, Frankfurt am Main)

Latour B, 2005, "From Realpolitik to Dingpolitik, or, how to make things public", in Making Things Public: Atmospheres of Democracy Eds B Latour, P Weibel (MIT Press, Cambridge, MA) pp $14-43$

Latour B, 2007, "La Terre est enfin ronde" Libération 1 February

Oosterling H, 2007, "Interest and excess of modern man's radical mediocrity: rescaling Sloterdijk's grandiose aesthetic strategy" Cultural Politics 2357 - 380

Serres M, 2000a The Birth of Physics translated by J Hawkes (Clinamen Press, London)

Serres M, 2000b Le Contrat Naturel (Flammarion, Paris)

Sloterdijk P, no date, "Stimmenfür Tiere: Phantasie über animalische Repräsentation", http://www.petersloterdijk.net/german/index.html

Sloterdijk, P, 1987a Critique of Cynical Reason translated by M Eldred (University of Minnesota Press, Minneapolis, MN)

Sloterdijk P, 1987b Kopernikanische Mobilmachung und ptolemaïsche Abrüstung: Ästhetischer Versuch (Suhrkamp, Frankfurt am Main)

Sloterdijk P, 1988 Zur Welt kommen-zur Sprache kommen. Frankfurter Vorlesungen (Suhrkamp, Frankfurt am Main)

Sloterdijk P, 1989 Eurotaoismus: Zur Kritik einer politischen Kinetik (Suhrkamp, Frankfurt am Main)

Sloterdijk P, 1990 The Thinker on Stage: Nietzsche's Materialism translated by J O Daniel (University of Minnesota Press, Minnesota, MN)

Sloterdijk P, 1993 Im selben Boot: Versuch über die Hyperpolitik (Suhrkamp, Frankfurt am Main)

Sloterdijk P, 1994 Weltfremdheit (Suhrkamp, Frankfurt am Main)

Sloterdijk P 1996 Selbstversuch: Ein Gespräch mit Carlos Oliveira (Carl Hanser, München)

Sloterdijk P, 1998a Sphären I. Blasen (Suhrkamp, Frankfurt am Main)

Sloterdijk P, 1998b Der starke Grund, zusammen zu sein (Suhrkamp, Frankfurt am Main)

Sloterdijk P, 1999 Sphären II. Globen (Suhrkamp, Frankfurt am Main)

Sloterdijk P, 2000, "Vivre chaud et penser froid", http://multitudes.samizdat.net/ vivre-chaud-et-penser-froid.html

Sloterdijk P, 2001a Nicht gerettet: Versuche nach Heidegger (Suhrkamp, Frankfurt am Main)

Sloterdijk P, 2001b Über die Verbesserung der guten Nachricht: Nietzsche's fünftes Evangelium (Suhrkamp, Frankfurt am Main) 
Sloterdijk P, 2001c Die Domestikation des Seins: Die Verdeutlichung der Lichtung (Suhrkamp, Frankfurt am Main)

Sloterdijk P, 2004 Sphären III: Schäume (Suhrkamp, Frankfurt am Main)

Sloterdijk P, 2005a, "Atmospheric politics", in Making Things Public: Atmospheres of Democracy Eds B Latour, P Weibel (MIT Press, Cambridge, MA) pp 944-951

Sloterdijk P, 2005b Im Weltinnenraum des Kapitals: Für eine philosophische Theorie der Globalisierung (Suhrkamp, Frankfurt am Main)

Sloterdijk P, Heinrichs H J, 2001 Die Sonne und der Tod: Dialogische Untersuchungen (Suhrkamp, Frankfurt am Main)

van Tuinen S, 2009, "Peter Sloterdijk's 'transgeneous philosophy': post-humanism, homeotechnique and the poetics of natal difference" Theory, Culture and Society

von Uexküll J, 1921 Umwelt und Innenwelt der Tiere (Springer, Berlin)

Whitehead A N, 2006 The Concept of Nature (Echo Library, London) 
Conditions of use. This article may be downloaded from the E\&P website for personal research by members of subscribing organisations. This PDF may not be placed on any website (or other online distribution system) without permission of the publisher. 